\title{
MOTIVATING THE STUDENTS TO READ ENGLISH MATERIAL BY USING FAIRY TALES OF THE EIGHTH YEAR STUDENTS AT SMP NEGERI 3 POLEWALI
}

\author{
Muthmainnah \\ Program Studi Pendidikan Bahasa Inggris \\ Universitas Al Asy'ariah Mandar \\ muthmainnahunasman@gmail.com
}

\begin{abstract}
The objective of this research is to find out the students' motivation in reading English material by using fairy tales. In this study, the researcher applied the descriptive method. The population of the research was the eighth year students of SMP Negeri 3 Polewali academic year 2012/2013 which consisted of 4 classes with 124 students. Because the number of students was large enough in number, the writer used random sampling method. The researcher took only 20 students as respondents. The instrument used to gather the data was questionnaire. The data from questionnaires were analyzed by frequency and percentage technique. The result of the data analysis shows that the Eighth year students of SMP Negeri 3 Pelewali have high motivation in reading English material by using Fairy Tales. It can be seen by the data obtained from the questionnaire in table 1 up 19 where shows that the average percentage of students who chosen very interesting is $43 \%$ and the students who chosen interesting is $48 \%$. So, the total is $91 \%$. It means that the students who chosen very interesting and interesting greater than $50 \%$. From the data collected above, it can be concluded that the using fairy tales can motivate students in reading English material.
\end{abstract}

Keywords: Motivation, Fairy Tales, Reading

\section{Abstrak}

Tujuan penelitian ini adalah untuk menemukan motivasi mahasiswa dalam membaca materi bahasa Inggris dengan menggunakan dongeng. Pada penelitian ini, peneliti menggunakan metode deskriptif. Populasi penelitian ini adalah siswa kelas VIII di SMP Negeri 3 Polewali tahun ajaran 2012/2013 yang terdiri dari 3 kelas dengan jumlah siswa sebanyak 124. Jumlah siswa yang banyak maka peneliti menggunakan metode random sampling. Peneliti hanya mengambil sebanyak 20 siswa sebagai responden. Hal tersebut dilihat dari data perolehan angket mulai tebel 1 sampai table 19 yang memperlihatkan tingkat rata-rata siswa dengan pilihan sangat tertarik sebanyak 43 persen dan tertarik sebanyak 48 persen. Jadi totalnya sebesar 91 persen. Artinya, siswa yang memilih jawaban sangat tertarik dan tertarik lebih dari 50 persen. Berdasarkan data yang telah dikumpulkan tersebut, maka dapat disimpulkan bahwa dengan menggunakan dongeng dapat memotivasi siswa dalam membaca materi bahasa Inggris.

Kata Kunci: Motivasi, Cerita Dongeng, Membaca

\section{INTRODUCTION}

\section{Background of Choosing the Subject}

Language is important in communication and used as a tool of communication among nation all over the world. As an international language, English is very important and has many interrelationshipwith various aspect of life. English is the first foreign language in our country which is taught from elementary level up to 
university level. English is also intensively used in international communication, in written as well as in spoken communication. In addition, science, technology, art and other books published are written in English.In today's world, learning English is a vital skill that would help the students achieve their full potential in later life. From the context, the Indonesian government has decided English as one of the compulsory subjects that should be taught as a foreign language for the student of elementary school up to university.

However, Indonesian students face some difficulties in learning English that is caused by language interference. As Hycraft (2001:8) stated that there are various skills in mastering language: respective skill which includes listening (understanding the spoken language), reading (understanding the written language), and productive skills which includes speaking and writing. The reading skill became very important in the education field. Student need to be exercised and be trained in order to have a good reading skill.

Reading is also something very important for the students because the success of their study depends on the greater part of their ability to read. If their reading skill is poor, they are very likely to fail in their study or at least they would have difficulty in making progress. On the other hand, if they have a good ability in reading, they would have a better chance to succeed in their study. To comprehend the text, the readers should be able to manage every part of the text, because it is easy to gain the comprehension in reading when the readers are to organize the text.

Most of the English teachers have difficulties to teach reading to Junior High School students, because most of the students are lack of vocabulary, motivation, and interest in reading. The students' motivation is one of the main aspects that support success learning. Motivation is an important factor since it can influence the success and the failureof someone. As Brown (2001:6) states that motivation is the difference that people say, between success and failure. If they are motivated, they would learn and if not they want that simplification may hold some of the time. Studying any subject without motivation and interest would make unsatisfactory result. It is different if the students are motivated to learn something that will do more than anyone who has predicated.

In language learning it is obvious that the more we read, the better command, and reading is easier and enjoyable. Through reading we are able to improve our English anywhere and anytime because reading can be carried out easily without a partner.

The skill of reading depends on the selected material. The material should be selected based on the student's vocabulary, background, and their needs. A beginner reader for example differs from a mature reader in concept of the development, knowledge of the world, skill used to obtain information, and strategies used to retain and recall information.

Considering the importance of reading ability to the learners of English, it is important to find out the way to improve reading ability and the way to motivate students to read English material. Giving fairy tales is one way that can be expected to 
motivate students to read fairy tales, the students are able to improve their language skill. They would have learned new words and appropriate expressions, they more sensitive to the correct uses of the language, and they will also learn good diction and style. As they learn to appreciate good materials, they will also be able to enjoy it better.

Another reason way we read fairy tales is that, although fairy tales are not about real people and real happenings, they often depict universal truth, about what may happen in real life. Thus, reading fairy tales opens up new world to us, it gives us experiences, which we cannot get otherwise. Based on the explanation above, the writer is interested in conducting a research under the title: "motivating the students to read English material by using fairy tales". It tends to build students' interest and motivation to read English material.

\section{THEORITICAL FRAMEWORK \\ The Concept of Motivation}

According to psychological research and theory," motivation is energy release by deprivation or the appearance of stimulus (Anderson 1981:1200). Motivation is concerned with why behavior occurs; why it starts, behavior will occur, how vigorous behavior, and why and when a particular behavior would stop. Variability's in behavior between people and within a person from time to time are often accounted for by differences in motivation.

According to Brown (1991:87), "Motivation is commonly thought of as an inners drive, impulse emotion or desire that moves one particular action. De Cecco and Crawford (1974:83) states that "motivation refers to those factors that increase and decrease of an individual's activity". Thus, it determines the levels or degree of his activity. Furthermore, they say that motivation is the term used to described what energizes a person and directs his or her activity.

In the context of classroom, motivation refers to such characteristics of student's behavior as interest, alertness, attention, concentration, and persistence. The significance of motivation for learning is usually assumed without question. The threat of punishment means by which the teacher can keep the pupil at work; on the other hand, interest, curiosity, and self selected goals keep the pupil at work without pressure from the teacher. The teacher has a choice between using specific goals or enlisting self activating motives or perhaps employing some combination of these. Motivation is also an aspect that is not less important in learning a language that attitude.

By some definition above, the researcher concluded that motivation goes had in reaching the target language. These two aspects, motivation and attitude influence the learning success or achievement. Especially in reading, the student can read well as long as they have inner desire or motivation to read. 


\section{The Concept of Fairy Tales}

Flanagan (2010:2) states that fairy tales is an English language term for a type of short narrative corresponding to the German term "maerchert or the Swedish "saga". Only a small number of the stories thus designated explicitly refer to fairies. Nonetheless, the stories may be distinguished from other folk narratives such as legends and traditions (which generally involve belief in the veracity of the events described) and explicitly moral tales, including beast fables. Fairy tales typically feature such folkloric characters as fairies, goblins, elves, tools, giants or gnomes, and usually magic or enchantments. Often the story will involve a far-fetched sequence of events.

Flanagan (2010:5) states that fairy tales are found in almost every culture and region of the world. For example, Japan, Russia, Sweden, Great Britain, and Germany have their own tales. Although the tones and plot may very they include the same universal elements that are described in the definition from dictionary.

a. Fairy tales fundamentals

1. Fairy tales at first glance seem simple but can be complex an may have happy or violent endings.

2. They often begin at a vague and unspecified point 'once upon a time' but can also be based on historical events.

3. Fairy tales have been relegated to children's literature, but are at the root of many narratives.

4. Fairy tales often depict opposites and extremes: good and evil, wealth and poverty.

b. Common themes and motifs

1. Escaping mighty and evil enemies

2. Accomplishing difficult tasks

3. Wisdom through suffering

4. Generosity, selfishness and pride, triumph of humility over greed

5. Triumph of the youngest, weakest, most oppressed

6. Animals: changing into animals, talking animals, animal helpers, companions and bridegrooms.

c. Plot, style and structure

1. Powerless underdog changes places with a more powerful person.

2. Happy endings: good rewarded and wicked punished

3. Minimal description, and reliance on formulaic patterns

4. Conventional beginnings ('once upon a time') and endings ('and they lived happily ever after').

Fairy tales are fictional stories that may feature folkloric characters (such as fairies, talking animals) and enchantments, often involving a far-fetched sequence of events. Fairy tales are part of folklore and these are some of their main characteristics:

1. Fairy tales will usually begin with "Once upon a time..."

2. Fairy tales happen very long time ago. 
3. Fairy tales create fantasy and make the readers believe in them unconsciously.

4. Fairy tales often describe extreme opposites such as good and evil characters or rich and poor family.

5. Royalty usually exist in a fairy tales, usually in the form of a beautiful princess or a handsome prince.

6. Magic is present in fairy tales, for example, there are dwarves, giants, elves, talking animals, witches, or fairies.

7. Fairy tales have a problem that needs to be solved.

8. It often takes three tries to solve the problem.

9. Fairy tales have happy endings as indicated by their most repeatedly last sentence "they all lived happily ever after".

After looking at their main characteristic, these are several justifications of using fairy tales in teaching language skill and cultures (Danan-djaja, 2002:86):

1. Fairy tales as part of folklore can be found everywhere in various forms. Every culture has various kinds of fairy tales which provide a vast array of source for teaching material. In addition, most familiar tales have been reproduced or adapted and are widely available; thus, these have added their popularity.

2. Fairy tales have universal values and plots add familiarity to students. Although each culture has its particular fairy tales, it is fascinating to recognize that there are some resemblances among certain fairy tales in different societies. "Cinderella" in Germany and "Bawang Merah and Bawang Putih" in Indonesia share similar themes of a girl who is being mistreated by her step-mother. Therefore, students can compare and contrast those cultures, events, or characteristics in these stories.

3. Fairy tales are enjoyable but meaningful. They signify human experience, values, and history; hence they can provide both entertainment and opportunities for further discussion. They set as an excellent example of the multifaceted mixture of history and fantasy. Moreover, they can be analyzed in short essays as well as in some more complicated research. Because of their universal values, similar plots and values, most people find it easy to remember fairy tales.

4. Fairy tales are short. This advantage has added more opportunities to use fairy tales in language classroom since teachers do not have to be afraid of adjusting most of their lesson plants when using fairy tales. Alternatively, teachers can assign their students to read them at home before further discussion in the next meeting.

5. Fairy tales are rich in terms of language yet grammatically complex and syntactically speaking than many other forms of literature. Their simplicity has made fairy tales consistent in style and form. 


\section{FINDINGS}

The following is the analysis of the data to show the frequency and percentage of the respondents who respond to each items of the questionnaire.

Table 1

The students' opinion towards reading.

\begin{tabular}{|c|c|c|c|}
\hline No & Classification & Frequency & Percentage \\
\hline 1 & Very Interesting & 15 & 75 \\
\hline 2 & Interesting & 5 & 25 \\
\hline 3 & Less Interesting & - & - \\
\hline 4 & Not Interesting & - & - \\
\hline & Total & 20 & 100 \\
\hline
\end{tabular}

Based on the table 1 above, out of 20 students, there were 15 students or $75 \%$ said very interesting. 5 students or $25 \%$ said interesting. None of the students said less interesting and not interesting. It indicates that most of the students said that reading is very interesting.

Table 2

Students' opinion about reading English

\begin{tabular}{|c|c|c|c|}
\hline No & Classification & Frequency & Percentage \\
\hline 1 & Very Important & 14 & 70 \\
\hline 2 & Important & 6 & 30 \\
\hline 3 & Less Important & - & - \\
\hline 4 & Not Important & - & - \\
\hline & Total & 20 & 100 \\
\hline
\end{tabular}

Based on the table 2 above, out of 20 students, there were 14 students or $70 \%$ said very important. 6 students or 30\% said important. None of the students said less important and not important. It indicates that most of the students said very important. It means that reading class was very important in English teaching.

Table 3

The students' opinion toward fairy tales.

\begin{tabular}{|c|c|c|c|}
\hline No & Classification & Frequency & Percentage \\
\hline 1 & Very Interesting & 5 & 25 \\
\hline 2 & Interesting & 13 & 65 \\
\hline 3 & Less Interesting & 2 & 10 \\
\hline 4 & Not Interesting & - & - \\
\hline & Total & 20 & 100 \\
\hline
\end{tabular}

Based on the table 3 above, out of 20 students, there were 5 students or $25 \%$ said very interesting. 13 students or $65 \%$ said interesting. 2 students or $10 \%$ said less interesting 
and none of the student said not interesting. It indicates that most of the students said interesting. It means that most of students were interesting about fairy tales.

Table 4

The Students' happy to read English reading materials in fairy tales

\begin{tabular}{|c|c|c|c|}
\hline No & Classification & Frequency & Percentage \\
\hline 1 & Very happy & 3 & 15 \\
\hline 2 & Happy & 15 & 75 \\
\hline 3 & Less happy & 2 & 10 \\
\hline 4 & Not happy & - & - \\
\hline \multicolumn{2}{|r|}{ Total } & 20 & 100 \\
\hline
\end{tabular}

Based on the table 4 above, out of 20 students, there were 3 students or $15 \%$ said very happy. 15 students or $75 \%$ said happy. 2 students or $10 \%$ said less happy and none of the student said not happy. It indicates that most of the students said happy. It means that most of the students were happy to read English reading materials in fairy tales.

Table 5

The students' efforts or way to get English reading materials.

\begin{tabular}{|c|c|c|c|}
\hline No & Classification & Frequency & Percentage \\
\hline 1 & Become customer & 1 & 5 \\
2 & Buying & 5 & 25 \\
3 & Borrow from library & 12 & 60 \\
4 & Borrow from friends & 2 & 10 \\
\hline \multicolumn{2}{|c|}{ Total } & 20 & 100 \\
\hline
\end{tabular}

Based on the table 5 above, out of 20 students, there were 1 student or $5 \%$ said become customer. 5 students or $25 \%$ said buying. 12 students or $60 \%$ said borrow from library and 2 student $\mathrm{s}$ said borrow from friends. It indicates that most of the students said borrow from library. It means that most of the students just borrow English reading materials from library.

Table 6

The students' feeling in spending their spare time to read fairy tales (various reading materials)

\begin{tabular}{|c|c|c|c|}
\hline No & Classification & Frequency & Percentage \\
\hline 1 & Very interesting & 9 & 45 \\
\hline 2 & Interesting & 8 & 40 \\
\hline 3 & Less interesting & 3 & 15 \\
\hline 4 & Not interesting & - & - \\
\hline & Total & 20 & 100 \\
\hline
\end{tabular}

Based on the table 6 above, out of 20 students, there were 9 students or $45 \%$ said very interesting. 8 students or $40 \%$ said interesting. 3 students or $15 \%$ said less interesting 
and none of the student said not interesting. It indicates that most of the students said very interesting. It means that most of the students were sometimes very interesting to spending their spare time to read fairy tales.

Table 7

The students' reactions when they were asked to read non-fictions by their teacher.

\begin{tabular}{|c|c|c|c|}
\hline No & Classification & Frequency & Percentage \\
\hline 1 & Do it happy & 9 & 45 \\
2 & Do it as a duty & 11 & 55 \\
3 & As usual & - & - \\
4 & Get angry or be bored & - & - \\
\hline \multicolumn{2}{|c|}{ Total } & 20 & 100 \\
\hline
\end{tabular}

Based on the table 7 above, out of 20 students, there were 9 students or $45 \%$ said do it happy. 11 students or $55 \%$ said do it as a duty. None of the students said as usual and get angry or be bored. It indicates that most of the students said do it as a duty. It means that most of the students were do it as a duty when they teacher asked them to read non-fictions.

Table 8

The students' attitude when they were asked to read fairy tales.

\begin{tabular}{|c|c|c|c|}
\hline No & Classification & Frequency & Percentage \\
\hline 1 & Very happy & 7 & 35 \\
\hline 2 & Happy & 10 & 50 \\
\hline 3 & Less happy & 2 & 10 \\
\hline 4 & Not happy & 1 & 5 \\
\hline \multicolumn{2}{|r|}{ Total } & 20 & 100 \\
\hline
\end{tabular}

Based on the table 8 above, out of 20 students, there were 7 students or $35 \%$ said very happy. 10 students or $50 \%$ said happy. 2 students or $10 \%$ said less happy and 1 student said not happy. It indicates that most of the students said happy. It means that most of the students fell stimulated when they asked to read fairy tales.

Table 9

The students' reaction when they find a word that did not know before when they read the fairy tales.

\begin{tabular}{|c|l|c|c|}
\hline No & \multicolumn{1}{|c|}{ Classification } & Frequency & Percentage \\
\hline 1 & Try to find it's meaning & 16 & 80 \\
2 & Only guess it's meaning & 1 & 5 \\
3 & Didn't care and keep reading & 2 & 10 \\
4 & Leave the materials and stop to read & 1 & 5 \\
\hline \multicolumn{2}{|c|}{ Total } & 20 & 100 \\
\hline
\end{tabular}


Based on the table 9 above, out of 20 students, there were 16 students or $80 \%$ said try to find it's meaning. 1 student or 5\% said only guess it's meaning. 2 students or $10 \%$ said didn't care and keep reading. 1 students said leave the materials and stop to read. It indicates that most of the students said try to find it's meaning. It means that most of the students had good response to the tasks that based on fairy tales.

Table 10

The students' opinion in they fell to understand the vocabulary from fairy tales.

\begin{tabular}{|c|c|c|c|}
\hline No & Classification & Frequency & Percentage \\
\hline 1 & Very easy & 1 & 5 \\
\hline 2 & Easy & 6 & 30 \\
\hline 3 & Very difficult & 11 & 55 \\
\hline 4 & Difficult & 2 & 10 \\
\hline & Total & 20 & 100 \\
\hline
\end{tabular}

Based on the table 10 above, out of 20 students, there were 1 student or $5 \%$ said very Easy. 6 students or $30 \%$ said easy. 11 students or 55\% said very difficult and 2 students said difficult. It indicates that most of the students said very difficult. It means that most of the students were in they fell very difficult to understand the vocabulary from fairy tales.

Table 11

The students' opinion about the teacher to use humorous stories in teaching process by using fairy tales.

\begin{tabular}{|c|c|c|c|}
\hline No & Classification & Frequency & Percentage \\
\hline 1 & Very often & 3 & 15 \\
\hline 2 & Often & 13 & 65 \\
\hline 3 & Sometimes & 4 & 20 \\
\hline 4 & Never & - & - \\
\hline \multicolumn{2}{|r|}{ Total } & 20 & 100 \\
\hline
\end{tabular}

Based on the table 11 above, out of 20 students, there were 3 students or $15 \%$ said very often. 13 students or $65 \%$ said often. 4 students or $20 \%$ said sometimes and none of the student said never. It indicates that most of the students said often. It means that most of the students were often about the teacher to use humorous stories in teaching process by using fairy tales. 
Table 12

The students' opinion about teacher in teaching materials related by using fairy tales

\begin{tabular}{|c|c|c|c|}
\hline No & Classification & Frequency & Percentage \\
\hline 1 & Very interesting & 4 & 20 \\
2 & Interesting & 14 & 70 \\
3 & Less interesting & 2 & 10 \\
4 & Not interesting & - & - \\
\hline \multicolumn{2}{|c|}{ Total } & 20 & 100 \\
\hline
\end{tabular}

Based on the table 12 above, out of 20 students, there were 4 students or $20 \%$ said very interesting. 14 students or $70 \%$ said interesting. 2 students or $10 \%$ said less interesting and none of the student said not interesting. It indicates that most of the students said interesting. It means that most of the students were interesting about teacher in teaching materials related by using fairy tales.

\section{Table 13}

That students' frequency in visiting library if various reading materials (fairy tales) were prepared.

\begin{tabular}{|c|l|c|c|}
\hline No & \multicolumn{1}{|c|}{ Classification } & Frequency & Percentage \\
\hline 1 & Become more diligent in visiting library & 5 & 25 \\
2 & As usual in visiting library & 13 & 65 \\
3 & Sometimes in visiting library & 2 & 10 \\
4 & Never in visiting library & - & - \\
\hline \multicolumn{2}{|c|}{ Total } & 20 & 100 \\
\hline
\end{tabular}

Based on the table 13 above, out of 20 students, there were 5 students or $25 \%$ said become more diligent in visiting library. 13 students or $65 \%$ said as usual in visiting library. 2 students or $10 \%$ said sometimes in visiting library and none of the student said never in visiting library. It indicates that most of the students said as usual in visiting library. It means that most of the students were as usual in visiting library in various reading materials (fairy tales) were prepared.

Table 14

The students' willingness to submit fairy tales tasks given by their teacher

\begin{tabular}{|c|c|c|c|}
\hline No & Classification & Frequency & Percentage \\
\hline 1 & Earlier & 7 & 35 \\
\hline 2 & On time & 13 & 65 \\
\hline 3 & Late & - & $\begin{array}{ll}- & -1\end{array}$ \\
\hline 4 & Not submite & - & - \\
\hline & Total & 20 & 100 \\
\hline
\end{tabular}

Based on the table 14 above, out of 20 students, there were 7 students or $35 \%$ said earlier. 13 students or $65 \%$ said on time. None of the student said late and not 
submite. It indicates that most of the students said on time. It means that most of the students had good response toward the task that based on fairy tales.

Table 15

The students' opinion on the statement that fairy tales could improve their reading motivation

\begin{tabular}{|c|c|c|c|}
\hline No & Classification & Frequency & Percentage \\
\hline 1 & Agree & 18 & 90 \\
2 & Disagree & 2 & 10 \\
\hline \multicolumn{2}{|c|}{ Total } & 20 & 100 \\
\hline
\end{tabular}

Based on the table 15 above, 18 students or $90 \%$ said agree, and 2 students or (10\%) said disagree. It indicates that most of the students said agree. It means that most of the students were agree that fairy tales could improve their reading motivation.

Table 16

The frequency of students in using fairy tales to study reading

\begin{tabular}{|c|c|c|c|}
\hline No & Classification & Frequency & Percentage \\
\hline 1 & Always & 8 & 40 \\
2 & Sometimes & 8 & 40 \\
3 & Seldom & 2 & 10 \\
4 & Never & 2 & 10 \\
\hline \multicolumn{2}{|c|}{ Total } & 20 & 100 \\
\hline
\end{tabular}

Based on the table 16 above, out of 20 students, there were 8 students or $40 \%$ said always. 8 students or $40 \%$ said sometimes. 2 students or $10 \%$ said seldom and 2 students or $10 \%$ said never. It indicates that most of the students said always and sometimes. It means that most of the students always and sometimes use fairy tales practicing their reading.

Table 17

The students' agreement if fairy tales become the main materials in reading class

\begin{tabular}{|c|c|c|c|}
\hline No & Classification & Frequency & Percentage \\
\hline 1 & Strongly agree & 6 & 30 \\
2 & Agree & 5 & 25 \\
3 & Disagree & 7 & 35 \\
4 & Strongly disagree & 2 & 10 \\
\hline \multicolumn{2}{|c|}{ Total } & 20 & 100 \\
\hline
\end{tabular}

Based on the table 17 above, 6 students or $30 \%$ said strongly agree. 5 students or $25 \%$ said agree. 7 students or $35 \%$ said disagree and 2 students or $10 \%$ said strongly disagree. It indicates that some of the students were disagree. It means that some of 
the students were disagree, but some students also agree if fairy tales is used as the main materials in reading class.

Table 18

The students' opinion about reading text by using fairy tales

\begin{tabular}{|c|c|c|c|}
\hline No & Classification & Frequency & Percentage \\
\hline 1 & Very interesting & 10 & 50 \\
\hline 2 & Interesting & 8 & 40 \\
\hline 3 & Less interesting & 2 & 10 \\
\hline 4 & Not interesting & - & - \\
\hline \multicolumn{2}{|r|}{ Total } & 20 & 100 \\
\hline
\end{tabular}

Based on the table 18 above, 10 students or $50 \%$ said very interesting. 8 students or $40 \%$ said interesting. 2 students or $10 \%$ said less interesting and none of the student said not interesting. It indicates that most of the students said very interesting. It means that most of the students were very interesting about reading text by using fairy tales.

\section{Table 19}

The students' opinion in if they read book they get difficult words

\begin{tabular}{|c|c|c|c|}
\hline No & Classification & Frequency & Percentage \\
\hline 1 & Always & 17 & 85 \\
\hline 2 & Rarely & 3 & 15 \\
\hline 3 & Sometimes & - & - \\
\hline 4 & Never & - & - \\
\hline \multicolumn{2}{|r|}{ Total } & 20 & 100 \\
\hline
\end{tabular}

Based on the table 19 above, out of 20 students, there were 17 students or $80 \%$ said always. 3 students or $15 \%$ said rarely. None of the student said sometimes and never. It indicates that most of the students said always. It means that most of the students were always read book they get difficult words.

\section{DISCUSSION}

This part, the researcher presents the discussion of the data analysis result collected through the questionnaire. The questionnaire was used to find out the students' motivation towards the use of fairy tales in the teaching of the English reading at SMP Negeri 3 Polewali to read English materials.

1. Item 15 the data shows that most of the students were agree, if fairy tales could improve their reading motivation, they are 18 (90\%).

2. Item 19 the data shows that most of the students chose option A. They are always read book they get difficult words. 17 (85\%). 
3. Item 9 the data shows that most of the students chose option A, they are 16 $(80 \%)$. They are try to find it's meaning when they find a word that did not know before when they read the fairy tales.

4. Item 1 the data shows that there are $15(75 \%)$ students have realized the very interesting about towards reading.

5. Item 4 the data shows that most of the students chose option B, 15 (75\%), they are interesting about to read English reading materials in fairy tales.

6. Item 2 the data shows that most of the students chose option $\mathrm{A}$, they are $14(70 \%)$. Reading class was very important in English teaching.

7. Item 12 the data shows that they are 14 (70\%) students were interesting about teacher in teaching materials related by using fairy tales.

8. Item 3 the data shows that most of the student are interesting, about fairy tales, they are $13(65 \%)$.

9. Item 11 the data shows that they are 13 students (65\%) interesting about the teacher to use humorous stories in teaching process by using fairy tales.

10. Item 13 the data shows that most of students chose option B, $13(65 \%)$, they are as usual in visiting library in various reading materials (fairy tales) were prepared.

11. Item 14 the data shows that most of the students $13(65 \%)$ are on time, if the willingness to submit fairy tales task given by their teacher.

12. Item 5 the data shows that they are 12 (60\%) students just borrow English materials from library.

13. Item 7 the data shows that there are $11(55 \%)$ students were doing it as a duty when they teacher asked them to read non-fictions.

14. Item 10 the data shows that most of the students are very difficult, they fell very difficult to understand the vocabulary from fairy tales, they are $11(55 \%)$.

15. Item 8 the data shows that most of the students chose option B, $10(50 \%)$. They are fell stimulated when they asked to read fairy tales.

16. Item 18 the data shows that most of the students option A, 10 (50\%). They are very interesting about reading text by using fairy tales.

17. Item 6 the data shows that there are $9(45 \%)$ students were very interesting. That most of the students were sometimes very interesting to spending their spare time to read fairy tales.

18. Item 16 the data shows that most of the students chose option A, $8(40 \%)$ and B, $8(40 \%)$. They are students always and sometimes use fairy tales practicing their reading.

19. Item 17 the data shows that most of the students chose option $C, 7$ (35\%). They are disagreeing, but some students also agree if fairy tales is used as the main material in reading class. 


\section{REFERENCES}

Anderson, B. Sacria. et all. 1981. Encyclopedia of Education. New York: Oxford University Press.

Brown, H Douglas. 2001. Teaching by Principles. San Francisco: Addison Wesley Longman, Inc.

Cook. 1994. SL and LT. A Sort of Motivation for Language Learning. New York : Longman Publisher

Danandjaja, James. 2002. Foklor Indonesia. Jakarta: Grafiti Pers.

Dawyer, Margaret A. 2003. "Same Strategis for Improving Reading Efficiency" English Teaching Forum. Vol. XXI No.3

De Cecco. Crowford, William. 1974. The Psychology of Learning and Introduction.

Flanagan, Mark. 2010. Fairy Tale; Contemporary Literature. New York: the New York Times Company.

Gage, L. and Berlier. 1984. Educational Psychology. New York: Cambridge University Press.

Gadner, R.C., \& Lambert, W.E. (1972). Attitudes and Motivation: Second language learning. Newbury House.

Gilmer. 1975. Motivation in Second Language Learning. London : Publishing Company.

Gwin, Thomas. 1990. "Language Skill Through Literature”. English Teaching Forum. Vol. XXVIII No. 3.

Harmer, Jerremy. 2006. The Practice of English Language Teaching. New York: Longman, Inc.

Harmer, Jeremy. 2004. The Practice of English Language Teaching. Third Edition. Malaysia : Longman.

Haycraf, John. 2001. An Introduction to English Language Teaching. London: Longman Group Limited.

Pelu, Hanafi. 2002. The Motivation of the Students of SMU Negeri 1 Leihitu Ambon to Learn English. Thesis FBS Unm.

Rubin, Dorothy. 1982. A Practical Approach to Teaching Reading. London: Oxford University Press.

Sudjana. 1992. Metode Statistika. Bandung : Tarsito Bandung.

Tandi, Nuriani. 2012. Improving the Students' Reading Skill Through Narrative Text at The Eleventh Class Students of SMK Kristen Sangalla'. Thesis Fkip UKIT. 